\title{
Chronicle on 2018 Africa Animal Welfare Conference and Africa Animal Law Convention
}

\author{
Amy P. Wilson \\ Attorney. Animal Law LL.M, Lewis \& Clark Law School, Portland, USA \\ Director and Co-founder Animal Law Reform South Africa
}

Received: December 2018

Accepted: December 2019

Recommended citation. WILSON A.P., Chronicle on 2018 Africa Animal Welfare Conference and Africa Animal Law Convention, dA. Derecho Animal (Forum of Animal Law Studies) 10/1 (2019) - DOI https://doi.org/10.5565/rev/da.400

\begin{abstract}
The 2nd Africa Animal Welfare Conference was held on 3rd to 5th September 2018 at the United Nations Environment Complex in Nairobi, Kenya. The event, which is an annual one, is organized by the Africa Network for Animal Welfare (ANAW) and is co-hosted by the United Nations Environment and the Government of Kenya. It provides a unique opportunity for relevant stakeholders (including veterinarians, NGOs, lawyers, farmers, judges, government, professionals and others) to come together and engage on topics relating to animal welfare, wildlife, environmental conservation and humans. This year, the Conference featured the "Africa Animal Law Convention" held concurrently on the second and third days of the Conference, sponsored and organized by the Center for Animal Law Studies at Lewis \& Clark Law School (based in Portland, Oregon, U.S.A). This was the first of its kind event held in Africa and featured animal law experts from the continent as well as the U.S.A and Europe, who presented on myriad subjects relating to the interaction between animals and the legal system. The theme for this year's conference was "People, Animals and The Planet: One Health, One Welfare", emphasizing the interconnectedness of these three pillars; the necessity to consider them in combination; and the call to utilize knowledge and skills to generate and implement homegrown solutions.
\end{abstract}

Keywords: Africa; Animal Law; Animal Welfare; Animals; People; Environment.

Resumen - Crónica sobre la Conferencia de Bienestar Animal en África 2018 y la Convención de Derecho Animal de África

La $2^{\text {a }}$ Conferencia africana de Bienestar Animal se celebró del 3 al 5 de septiembre de 2018 en el Complejo de las Naciones Unidas para el Medio Ambiente en Nairobi, Kenia. El evento, que es anual, está organizado por la Africa Network for Animal Welfare (ANAW) y está dirigido conjuntamente por las Naciones Unidas para el Medio Ambiente y el Gobierno de Kenia. Brinda una oportunidad única para que las partes interesadas (incluidos veterinarios, ONG, abogados, agricultores, jueces, gobiernos, profesionales y otros) se reúnan y participen en temas relacionados con el bienestar animal, la vida silvestre, la conservación del medio ambiente y los seres humanos. Este año, la Conferencia presentó la "Convención de Derecho Animal de África" celebrada simultáneamente en el segundo y tercer día de la Conferencia, patrocinada y organizada por el Center for Animal Law Studies at Lewis \& Clark Law School (con sede en Portland, Oregón, EE. UU.). Este fue el primer evento de este tipo que se realizó en África y contó con expertos en derecho animal del continente, así como en los Estados Unidos y Europa, que presentaron numerosos temas relacionados con la interacción entre los animales y el sistema jurídico. El tema de la conferencia de este año fue "Gente, animales y el planeta: una salud, un bienestar", enfatizando la interconexión de estos tres pilares; la necesidad de considerarlos en combinación; y el llamado a utilizar el conocimiento y las habilidades para generar e implementar soluciones de cosecha propia.

Palabras clave: África; Derecho Animal; Bienestar Animal; Personas; Medioambiente. 
The $2^{\text {nd }}$ Africa Animal Welfare Conference was held on $3^{\text {rd }}$ to $5^{\text {th }}$ September 2018 at the United Nations Environment Complex in Nairobi, Kenya. ${ }^{1}$

The event, which is an annual one, is organized by the Africa Network for Animal Welfare (ANAW) and is co-hosted by the United Nations Environment and the Government of Kenya. It provides a unique opportunity for relevant stakeholders (including veterinarians, NGOs, lawyers, farmers, judges, government, professionals and others) to come together and engage on topics relating to animal welfare, wildlife, environmental conservation and humans.

This year, the Conference featured the "Africa Animal Law Convention" held concurrently on the second and third days of the Conference, sponsored and organized by the Center for Animal Law Studies at Lewis \& Clark Law School (based in Portland, Oregon, U.S.A). ${ }^{2}$ This was the first of its kind event held in Africa and featured animal law experts from the continent as well as the U.S.A and Europe, who presented on myriad subjects relating to the interaction between animals and the legal system.

The theme for this year's conference was "People, Animals and The Planet: One Health, One Welfare", ${ }^{3}$ emphasizing the interconnectedness of these three pillars; the necessity to consider them in combination; and the call to utilize knowledge and skills to generate and implement homegrown solutions.

Many strides have been made so far by different stakeholders in Africa to promote animal welfare and Wildlife and Environmental Conservation across Africa. This is in appreciation of ongoing efforts, but at the same time being cognizant of various gaps and challenges facing animal welfare and conservation in Africa.". The need is relevant now more than ever, given the current state and the broad impact across sectors. ${ }^{4}$ These include but are not limited to: species extinction and loss of biodiversity; increasing impact on human and animal health (emerging infectious diseases and anti-microbial resistance); climate change; environmental degradation and crimes (habitat loss, affect on soils and exploration and mining around/in protected areas); wildlife and animal crimes; dependency on animals for livelihoods; other related issues. It is increasingly clear that a cross-sector approach needs to be adopted and the input and action of all stakeholders is critical.

Positively, there is a growing recognition of these impacts and their intersection, not only by those involved in animal practices and professions, but by policy makers and Government. There has been huge momentum for animal welfare over the last decade, and the movement is only growing. The issue of animal welfare is no longer incidental but mainstream. Not only does the Conference illustrate this, but also the recent development of the Animal Welfare Strategy for Africa (AWSA) ${ }^{5}$ by the African Union (AU) - a first for Africa.

This continental animal welfare strategy is in line with the Universal Declaration on Animal Welfare $(\mathrm{UDAW})^{6}$ and the standards of the World Organization for Animal Health (OIE), but takes into account the unique African context. While the AWSA is meant to "enhance collaboration, cooperation, coordination and partnerships with specialized organizations, and engage in the formulation of a common African position on animal welfare during the OIE [World Animal Health Organisation] standard setting and approval processes" ${ }^{\prime 7}$, it notably contains an express recognition of the sentience of animals, a unique inclusion in AU policies.

For purposes of this Chronicle, the Conference and the Convention have been dealt with separately in two parts, with a greater emphasis on the Convention, given the audience of this Chronicle. In addition, due to the number of presentations over the few days, only summaries of certain presentations have been provided. ${ }^{8}$

\footnotetext{
${ }^{1}$ A full Report on the Conference can be found here: ANAW Website: https://www.aawconference.org/conferencereports/Africa Animal Welfare Conference Report 2018.pdf. [Last Accessed 7 December 2018]. It is suggested that this be consulted for a detailed review of the Conference, its objectives, outcomes, presentations, attendees and other relevant information.

${ }^{2}$ A short report on the Convention from the Center for Animal Law Studies at Lewis \& Clark Law School can be accessed here: Lewis \& Clark Law School Website: https://law.lclark.edu/live/news/39384-the-center-for-animal-law-studies-sponsors-first [Last Accessed 7 December 2018]

${ }^{3}$ Full concept note can be accessed here: ANAW Website: https://www.aawconference.org/index.php/en/about-the-conference [Last Accessed 7 December 2018]

${ }^{4}$ Aside from the welfare of the animals themselves - and their own interests in being protected.

${ }^{5}$ Released by the African Union in 2017 through the Africa Platform for Animal Welfare (APAW) with the secretariat at AU-IBAR Full Strategy can be accessed here: World Animal Net Website http://worldanimal.net/images/stories/documents/Africa/AWSA.pdf [Last Accessed 7 December 2018]

${ }^{6} \mathrm{https}$ ://www.ifaw.org/united-states/our-work/political-advocacy/udaw-universal-declaration-animal-welfare [Last Accessed 7 December 2018]

${ }^{7}$ Supra note 4

${ }^{8}$ Please see Report for full summaries of each presentation.
} 


\section{Part I: Conference}

The Conference opened with everyone in high spirits and a call for prayers by religions represented. The Conference overview and objectives were set out and key stakeholders were given the opportunity to make some opening remarks and goodwill messages. ${ }^{9}$ Although these varied, the golden thread was the acknowledgement of the need to consider interdependent sustainable solutions in order to bring about meaningful change to humans, animals and the environment. We also need to ensure the involvement of all stakeholders, particularly in communities. It is only through this approach can we begin to achieve real change or development for Africa.

Indeed, regardless of the specific subject matter of the panels and sessions throughout the Conference, these sentiments were clearly visible. Another common acknowledgement was the unique and important relationship that African people have with animals as well as the need to reconsider animal welfare - not as a Western concept (as it may traditionally have been / is being done) - but rather to look at it from an African perspective. This is an important ideology when one is looking for realistic, sustainable solutions.

The Conference sessions commenced with a presentation by Dr. Mwenda Mbaka ${ }^{10}$ exploring "Animals in the Web of Life" and how animals are an "essential linkage to a healthy environment, better health and sustainable livelihoods". Mbaka discussed the vision, mission, goal and strategic objectives of the AWSA. Some key points included the treatment of animals as "sentient beings" and noting the need to transform the animal resources industry through adoption of good animal welfare practices for human wellbeing, sustainable livelihoods, poverty reduction and economic growth". ${ }^{11}$

Important was to look at the animal - recognise not only the physical and physiological needs - but also consider their psychological states. He illustrated the rise in the concern for the welfare of animals by quoting progressive statements made by prominent African people and iterated the requisite for Africa-centric narratives about animal welfare to drive the animal welfare agenda in Africa.

Following this, attendees had the choice to attend one of two breakaway sessions. The first, entitled "Wildlife" 12 covered several topics including wildlife crime such as poaching and trafficking in Kenya and the incidences of negligence in translocation of animals. It further explored the issue of wildlife extinction and the numerous threats faced by animals. Some of the recent technological innovations in conservation were highlighted and their impact on animal protection. In closing, the pressing issue of human-animal conflict was explored and particularly, a project in Tsavo National Park in Kenya which provides water to elephants in times of drought and an indication that other specific actions could similarly reduce such conflicts in future.

The second breakaway session dealt with "Animal Production Systems" 13 and delved into a few of the trending issues such as slaughterhouses, and the move towards more humane methods of slaughter; the projected growth of the demand for animal agriculture in Africa as well as the importance of engaging with youth on these issues if we are to bring about change. Lastly, the highly pertinent subject of antimicrobial resistance and how this is related to current methods of animal production was explored.

The first day concluded with a session on the "State of the World" ${ }^{14}$ which explored topics ranging from the role of the judiciary in environmental law to engaging the community and the positive results this can have. It also examined human and animal cancers; genetically modified organisms and linking sustainable development goals to one health \& one welfare. This ended the first day, and delegates used the opportunity network and deliberate on the day's activities.

The first part of Day 2 of the Conference covered matters mostly relating to the United Nations

\footnotetext{
${ }^{9}$ Supra note 1. Presenters included Ambassador Nehemiah Rotich (Conference Chair); Monika Gail Mac Devette (Deputy Division Director; UN Environment); Tennyson Williams (Regional Director; World Animal Protection); Alex Mayers (Donkey Sanctuary); Dawn Moncrief (Founding Director; A Well Fed World); Pamela Frasch (Associate Dean of Animal Law and Executive Director; Centre for Animal Law Studies at Lewis \& Clark Law School); Dr. Obadiah Njagi (Director of Veterinary Services; Ministry of Agriculture, Livestock, Fisheries and Irrigation, Republic of Kenya)

${ }^{10}$ Chairman of the Kenya Veterinary Board

${ }^{11}$ Africa Animal Welfare Conference Website: https://www.aawconference.org/2018 Presentations/AnimalsAn_Essential_Linkage_to_Environmental_Health_Public_Health_and_Sustainable_Livelihoods.pdf [Last Accessed 7 December 2018]

${ }^{12}$ Presenters included Jim Karani (Wildlife Direct); Eunice Robai (ANAW); Mainza Moono (400ft Inc.); and Patrick Mwalua (Water for Elephants Project)

${ }^{13}$ Presenters included: Dr. Diana Onyango (Kenya Society for the Prevention of Cruelty to Animals); Tozie Zokufa (A Greener World); and Dr. Yewandae Alimi (A-CDC Factory Farming)

${ }^{14}$ Presenters included: hon. Lady Justice Antonina Kossy Bor (Judge, Environment and Lands Court); Professor Hanes Herbert Williams (Arizona State University, USA); Dr. Edwin Sabuhiri (President, Gorilla Guardians, Rwanda), Dr. Kelvin Momanyi (Senior Lecturer, Department of Biochemistry and Biotechnology, Kenyatta University); Dr. Daniel Maingi, Executive Director, Growth Partners Africa
} 
Environment Program (UNEP) and some relevant considerations applicable to the United Nations Environment Assembly (UNEA), which will gather in Nairobi, Kenya from 11 - 15 March 2019. ${ }^{15}$ These included the outcomes and objectives of the UNEA and opportunities for major groups on how to engage with the UNEA.

The next Panel on "Innovative Solutions for Environmental Challenges and Sustainable Consumption and Production", ${ }^{16}$ opened with an introduction to UNEP's private sector and how it helps with land restoration and wildlife conservation. It went on to discuss how religious and faith organisations are playing a role in environmental care and how important empowering the youth is, for future efforts. The final panelist gave a frank breakdown of factory farming and its global impact, including as a driver for climate change. He emphasized the need for food system reform and discussed some of the current viable alternatives that exist.

Working animals and their welfare was the next topic of the day, ${ }^{17}$ which is critically important due to the heavy reliance of communities in Africa on this group., particularly, donkeys and horses. Their role in human livelihoods connects their welfare with the sustained reliance thereon. The panel also explored the rising demand for donkey skin and the question as to whether breeding farms are a feasible solution to address the demand. The final presenter discussed solid waste and its impact, given the number of donkeys and necessity of developing best practices for animal waste.

The second day's deliberations concluded with a review of sustainability and the sundry of issues falling under this umbrella. ${ }^{18}$ Presenters discussed plastic and its impact on our oceans and marine life; the causes and consequences of industrialization and emerging infectious and lifestyle diseases.

The final day of the Conference was initiated by presentations related to "Leadership and Funding" and important aspects in relation to these concepts. ${ }^{19}$ Presenters discussed the need for leaders to be flexible and evolve with the times - a "one size fits all" approach, will simply not work in Africa nor in today's times. Also emphasized was the requirement for communities, as critical role players and stakeholders in conserving wildlife combatting wildlife crimes, to have a voice in these discussions, and for leaders to follow regenerative principles.

The ultimate Conference Session ${ }^{20}$ ended some practical advice for participants on "Building Endurance-Setting Your Priorities Right" which was an interactive session among different stakeholders to equip them with knowledge on some of the important matters to be considered by them, particularly with regard to grants and funding.

Delegates then gathered for an interactive session to draft resolutions from the Conference. In summary, participants resolved to: ${ }^{21}$

1. Increase engagement with the United Nations and its members to promote the relevance of Animal Welfare to the achievement of Sustainable Development Goals;

2. Encourage liaison with different stakeholders in the sensitization of animal welfare and developing a critical mass of sensitized public who can champion animal welfare;

3. Work towards the formulation, enactment and review of policy to develop current standards of animal welfare, taking into account legislation in the field of animal welfare and the environment;

4. Involve youth in developing a model blue print of environmental and animal welfare sustainability;

5. Appeal to government and non-governmental organizations to integrate policy on the environment, animals and people in a holistic approach as opposed to sectorial approach;

6. Integrate sustainable consumption and production in animal welfare and the environment;

7. Stress the need for measurable ways of assessing impact and tracing progress in animal welfare and the environment;

\footnotetext{
${ }^{15}$ Presenters included Charlotte Ndakorerwa, Civil society engagement at UNEP); Laetitia Zobel/ Charles Arden Clarke- One Planet Network (10YFP) Sustainable Consumption and Production Programme of UNEP

${ }^{16}$ Panelists included Kamar Yusuf (UNEP Private Sector unit); Allan Ottaro (Director of Catholic Youth Network of Environmental Sustainability in Africa); and Wolf Gordon Clifton (Director of Animal People)

${ }^{17}$ Presenters included Penny Ward (World Horse Welfare); Alex Mayers, Donkey Sanctuary and Bojia Duguma (Donkey Sanctuary Ethiopia)

${ }^{18}$ Dr. Gabriela Kaplan (President, Lifewatch Group); Innocent Maloba (WWF); Paul Karanja (Sustainable Agriculture Community Development Programme and Dr. Anteneh Roba (International Fund for Africa)

${ }^{19}$ Presenters included Tennyson Williams (Regional Director, World Animal Protection Presentation); Michael O’Brien Onyeki (Senior Vice President-Africa Region, Conservation International. Leadership and Civil Society Governance); and Prof. Janet Rumfelt (Regis University, Denver, USA)

${ }^{20}$ Nancy Chege (Country Programme Manager, GEF Small Grants Programme); and Dr. Michael Kilpatrick (Senior Advisor, Good Financial Grant Practice Programme, The African Academy of Sciences)

${ }^{21}$ Supra note 1.
} 
8. Agree to participate in crafting animal laws in Africa;

9. Support the development of strategic frameworks for animal welfare in Africa;

10. Pursue engagements with humanitarian agencies to improve the welfare of animals, especially animals in disaster situations;

11. Encourage partnerships with accredited legal institutions to incorporate animal law into legal curriculums;

12. Capacity building animal welfare, wildlife and environmental civil society organizations in Africa on governance and advocacy matters.

Although these resolutions are ambitious, they are intended to operate as a base framework for key objectives and actions going forward. As the famous African proverb goes "If you want to go quickly, go alone. If you want to go far, go together." It is though efforts like these and integrated solutions across localities, disciplines and groups that meaningful change will come about for all.

Noticeably, throughout the Conference was the manner in which the 259 delegates respectfully engaged with each other on issues, despite their different backgrounds and perspectives. This led to a platform ideal for exchange of ideas and experiences and provided a positive learning environment. As the concept note specified, it is necessary to development of a critical mass of sensitized civil society organizations and animal welfare stakeholders in Africa who can champion and support the animal welfare agenda in Africa.

The 2019 Africa Animal Welfare Conference will be held at the United Nations Economic Commission for Africa in Addis Ababa, Ethiopia on $2^{\text {nd }}$ to $4^{\text {th }}$ September 2019, the theme is still to be confirmed. ${ }^{22}$

\section{Part II: Convention}

The Convention was the first of its kind and in terms of scale in Africa, focusing specifically on animal law across different countries, with the majority of presenters composed of graduates of the Lewis \& Clark Law School Animal Law LL.M Program. This first Convention was a joint venture of ANAW and CALS' dedicated international animal law program focused on developing the field of animal law in Africa, primarily. This program is directed by Natasha Dolezal. Together, Josphat Ngonyo and Natasha, decided to hold the first animal law focused event as part of the larger AAWC in order to connect the issues facing humans, the environment and animals while also providing a solid foundation from which to present the field to a larger, diverse audience. The speakers, from Kenya and South Africa, illustrated the immensity of the field of animal law through the topics canvassed over the two-day Convention and drew from their own experiences, interests and relevant expertise.

The Center for Animal Law Studies, through the support of donors, was able to subsidize the cost of attendance for fifty law students from local law schools in Kenya. For many of these students, this was their first exposure to the subject, which is not yet taught in any Universities in Kenya (or the African continent). ${ }^{23}$ Most of the students are currently pursuing other areas of study (including some animal related, such as veterinary science and conservation and others) but have an interest in animal protection and this was a unique opportunity for them to hear about these issues from some of the top experts, and the role of law in these issues. Other attendees included teachers, with a keen interest on engaging with their students and other youth on these, having realized the importance of education in changing the world.

The Convention convened with Pamela Frasch, ${ }^{24}$ explaining the field of animal law as well as its rapid growth in legal education. For many years, the Center for Animal Law Studies has been a pioneer on the subject of animal law, focusing on educating the next generation of animal lawyers. Students come from all around the world, with the goal of receiving the tools and knowledge to equip them to ensure animal interests are accounted for in the legal system in their countries.

Also making introductory remarks was the Executive Director of ANAW, Josphat Ngonyo, who emphasized the need to have animals' needs accounted for in the legal system. He illustrated the burgeoning nature of this field and the growing concern for animals by referring to the fact that just a few of years ago, the Africa Union (AU) did not want anything to do with animal welfare. In 2011 for example, this concept

\footnotetext{
${ }^{22}$ More information on the Conference can be found here: Africa Animal Welfare Conference Website: https://www.aawconference.org/index.php/en/ [Last Accessed 7 December 2018]

${ }^{23}$ According to: "Animal Law Courses Globally" Search

https://www.google.com/maps/d/u/0/viewer?mid=1Hdgt9cZy JxSsv0QnAmJ xAKQbU\&ll=-6.361109362927034e14\%2C0\&z=1\&fbclid=IwAR2TZ6TcPc-LdtSdzj3rQ5AQj7sqxmMdWD2i9VUBKdZIDBb4GUwAU7baBCc [Last Accessed 7 December 2018]

${ }^{24}$ Associate Dean of the Animal Law Program 
did not feature in policies. Yet, in 2018, the AU has an entire dedicated strategy on the subject as well as dedicated bodies. He emphasized that there is clearly scope for growth in this area as well as job opportunities.

The next session entitled "Defending Africa's Wildlife" 25 discussed some of the threats facing wildlife today, compared the legal frameworks relating to wildlife in South Africa and Kenya and probed the subject of consumptive use of wildlife as a model for conservation in Africa. More particularly, given the recent action by the Kenyan government to consider the consumptive use of their wildlife (vs. non-consumptive use such as eco-tourism), it is important to look at how this model has or has not worked in other countries. Using South Africa and their policies relating to lions, rhinos and elephants as a case study, the conversation engaged with some of the potential advantages and disadvantages of this approach and what can Kenya learn from their successes or failures. The session ended with some proposed legal principles and safeguards that would, out of necessity, need to be included if this model were to be adopted.

The last session of the first day saw a dialogue on "Crimes Against Animals - Challenges in Prosecution" was presented by two prosecutors with the ODPP in Kenya. ${ }^{26}$ The conversation touched on the need for Kenyan people to be aware of issues relating to animal welfare and expand their scope of animals to not only include wildlife (as has been the general approach up to now), but also to include other categories of animals including but not limited to companion animals. As prosecutors, the speakers put forward some of the challenges they have experienced in their work on animal related cases, such as archaic laws that fail to stipulate sufficient penalties for animal welfare violations, competing interests and cultural considerations and a general lack of understanding on these issues from relevant stakeholders, including the public.

The second day of Convention (Day 3 of Conference) commenced with Wachira Kariuki (the Legal Officer for ANAW) engaging the topic of "Animal Welfare Protection Systems". He emphasized that in order for animals to be protected, all stakeholders need to come together and there must be laws and legal systems that govern how animals are treated and effective enforcement. He also discussed the matter of animals is disasters and the need for "specialized neutral animaltarian agencies" to assist these animals and work together with the humanitarian agencies.

For the penultimate session, a presentation on "Animal Law Education - Where to Start?", the Honorable Allan Temba Sitati discoursed the role of magistrates in animal law education. He looked at the legal frameworks currently in place and how these can be utilized to promote animal law education and legal information. Advocate Winnie Nyaboke Onkoba highlighted the reasons why animals need our protection and how to achieve this through (inter alia) sensitization on the importance of animals, putting in place proper legislation and punishing animal offenders.

The Convention wrapped up with a session by Hon. Justice Nzioki wa Makau and Natasha Dolezal (Director of the International Animal Law Program at CALS) entitled " Moving Forward - Opportunities in Animal Law in Africa and Around the World" where the speakers discussed the necessity of having animal lawyers but also other stakeholders looking out for their interests, including NGOs, veterinarians, officials, government, practitioners and others. Even students can get involved and make a change. Natasha, who was instrumental in organizing the Animal Law Convention, mentioned the opportunity for lawyers to study a specialized LL.M. degree in Animal Law at Lewis \& Clark and the availability of scholarships for international students.

Personally, as an attendee and speaker at the Conference, I found the event extremely stimulating and motivating. It was remarkable to meet and be surrounded by so many passionate people coming together for the common goal of advancing animal welfare in a way that is beneficial to animals, people and the environment. It was inspiring to hear the different perspectives from the broad variety of stakeholders, learn about specific issues faced, share ideas and experiences and look forward as to how to make realistic and lasting impacts that affect us all. Particularly moving for me was engaging with the students and others who attended the Convention and canvassing their viewpoints on different subjects. Their role in ensuring animal welfare in Africa cannot be overemphasized.

\section{Bibliography}

1. "Animal Law Courses Globally" Search https://www.google.com/maps/d/u/0/viewer?mid=1Hdgt9cZy JxSsv0QnAmJ xAKQbU\&ll=$6.361109362927034 \mathrm{e}-14 \% 2 \mathrm{C} 0 \& \mathrm{z}=1 \& \mathrm{fbclid}=$ IwAR2TZ6TcPcLdtSdzj3rQ5AQj7sqxmMdWD2i9VUBKdZ1DBb4GUwAU7baBCc [Last Accessed 7 December 2018]

\footnotetext{
${ }^{25}$ Jim Karani (Wildlife Direct) and Amy P. Wilson (Animal Law Reform South Africa)

${ }^{26}$ Rodah Ogoma and Gikui Gichuhi
} 
2. Africa Animal Welfare Conference Website:

https://www.aawconference.org/conferencereports/Africa_Animal_Welfare_Conference_Report 2 018.pdf. [Last Accessed 7 December 2018]. It is suggested that this be consulted for a detailed review of the Conference, its objectives, outcomes, presentations, attendees and other relevant information.

3. Africa Animal Welfare Conference Website: https://www.aawconference.org/index.php/en/aboutthe-conference [Last Accessed 7 December 2018]

4. Africa Animal Welfare Conference Website: https://www.aawconference.org/2018 Presentations/AnimalsAn_Essential_Linkage to Environmental_Health_Public_Health_and_Sustainable_Livelihoods.p df [Last Accessed 7 December 2018]

5. Animal Welfare Conference Website: https://www.aawconference.org/index.php/en/ [Last Accessed 7 December 2018]

6. Lewis \& Clark Law School Website: https://law.lclark.edu/live/news/39384-the-center-foranimal-law-studies-sponsors-first [Last Accessed 7 December 2018]

7. Universal Declaration for Animal Welfare Website: https://www.ifaw.org/united-states/ourwork/political-advocacy/udaw-universal-declaration-animal-welfare [Last Accessed 7 December $2018]$

8. World Animal Net Website http://worldanimal.net/images/stories/documents/Africa/AWSA.pdf [Last Accessed 7 December 2018]

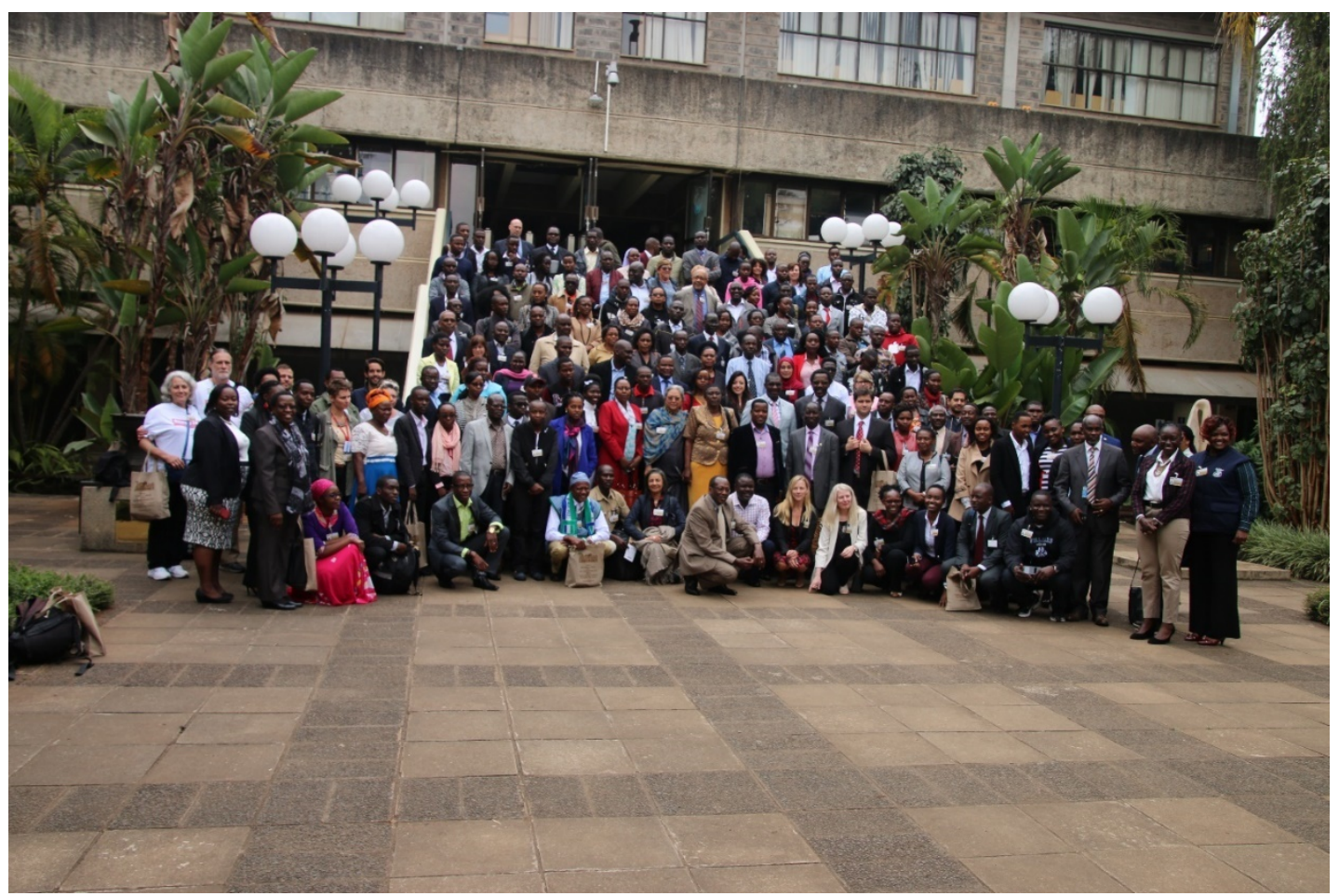

Delegates of the Conference ((Source: Accessed through Google Drive

Link: https://www.aawconference.org/index.php/en/about-the-conference/2018-conference-photos) 


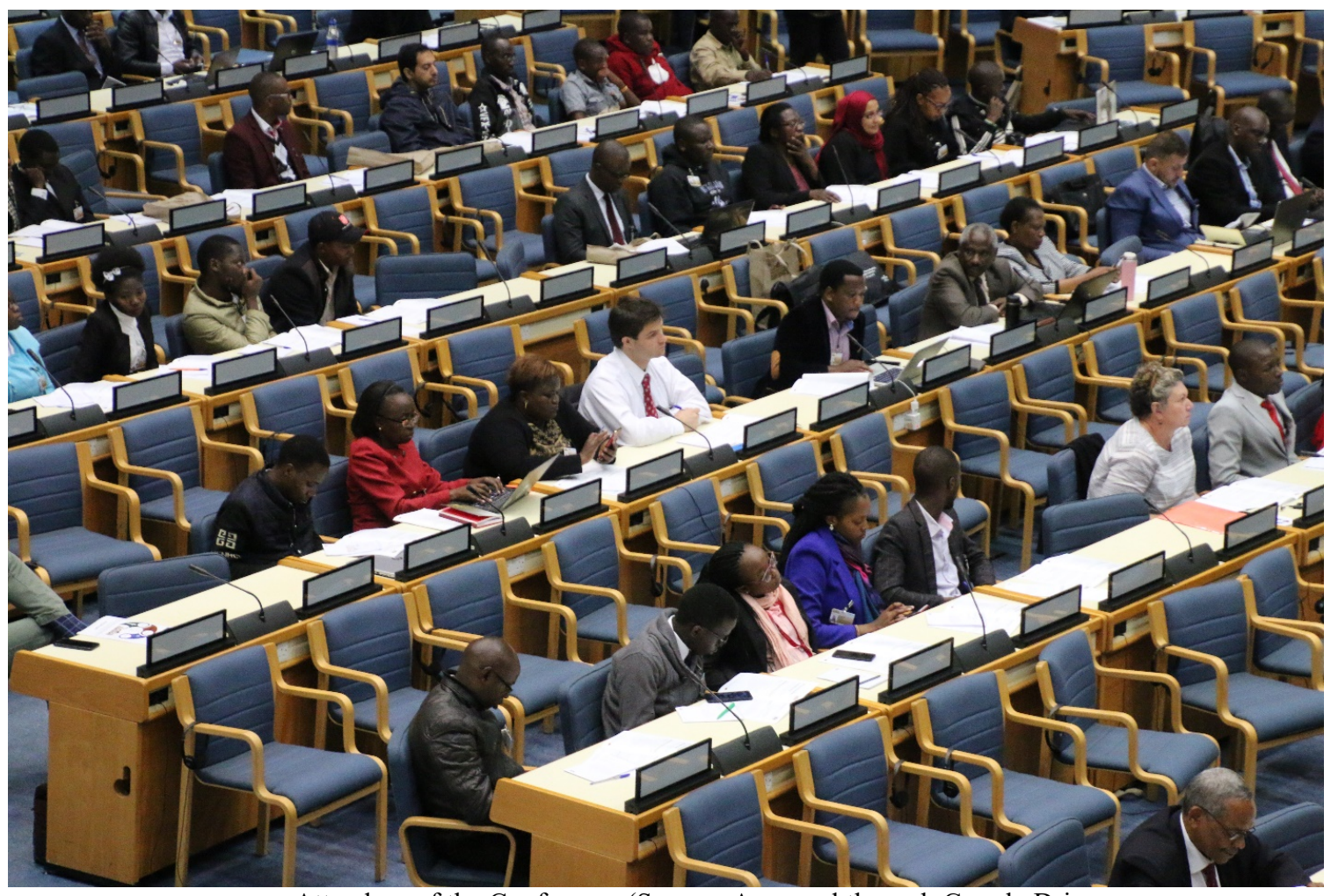

Attendees of the Conference (Source: Accessed through Google Drive Link: https://www.aawconference.org/index.php/en/about-the-conference/2018-conference-photos)

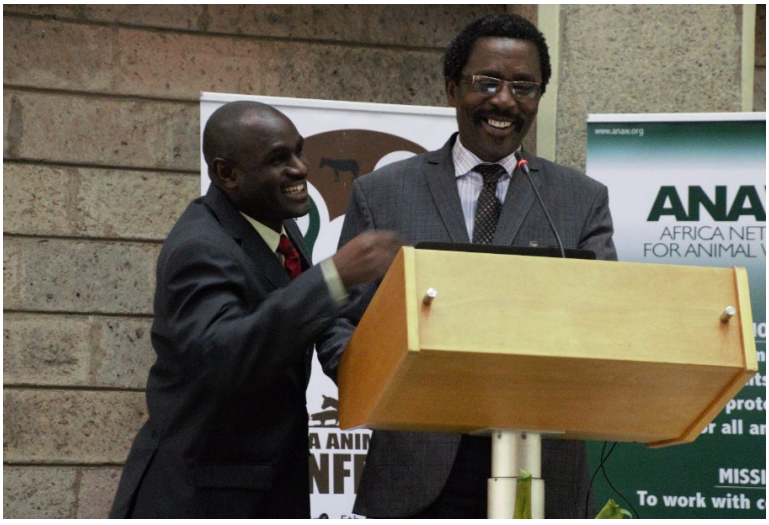

A warm exchange between delegates

(Source: Accessed through Google Drive Link: https://www.aawconference.org/index.php/en/aboutthe-conference/2018-conference-photos)

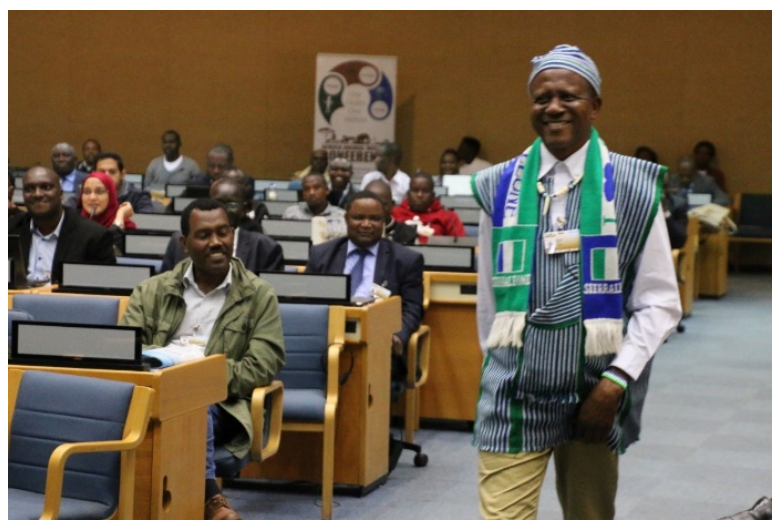

Some opted for traditional attire

(Source: Accessed through Google Drive Link: https://www.aawconference.org/index.php/en/aboutthe-conference/2018-conference-photos) 


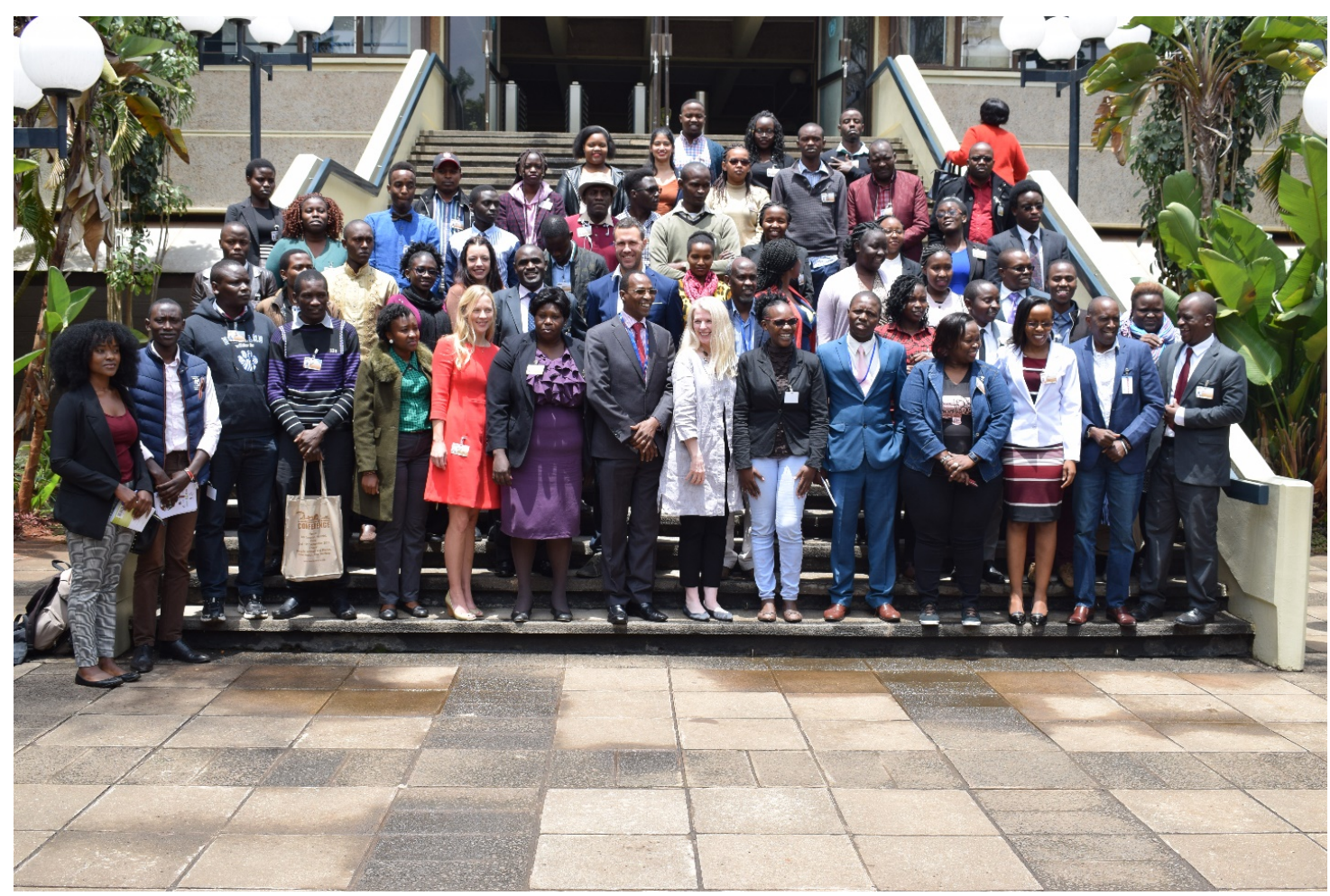

Some of the attendees of Africa's first Animal Law Convention (Source: Accessed through Google Drive

Link: https://www.aawconference.org/index.php/en/about-the-conference/2018-conference-photos)

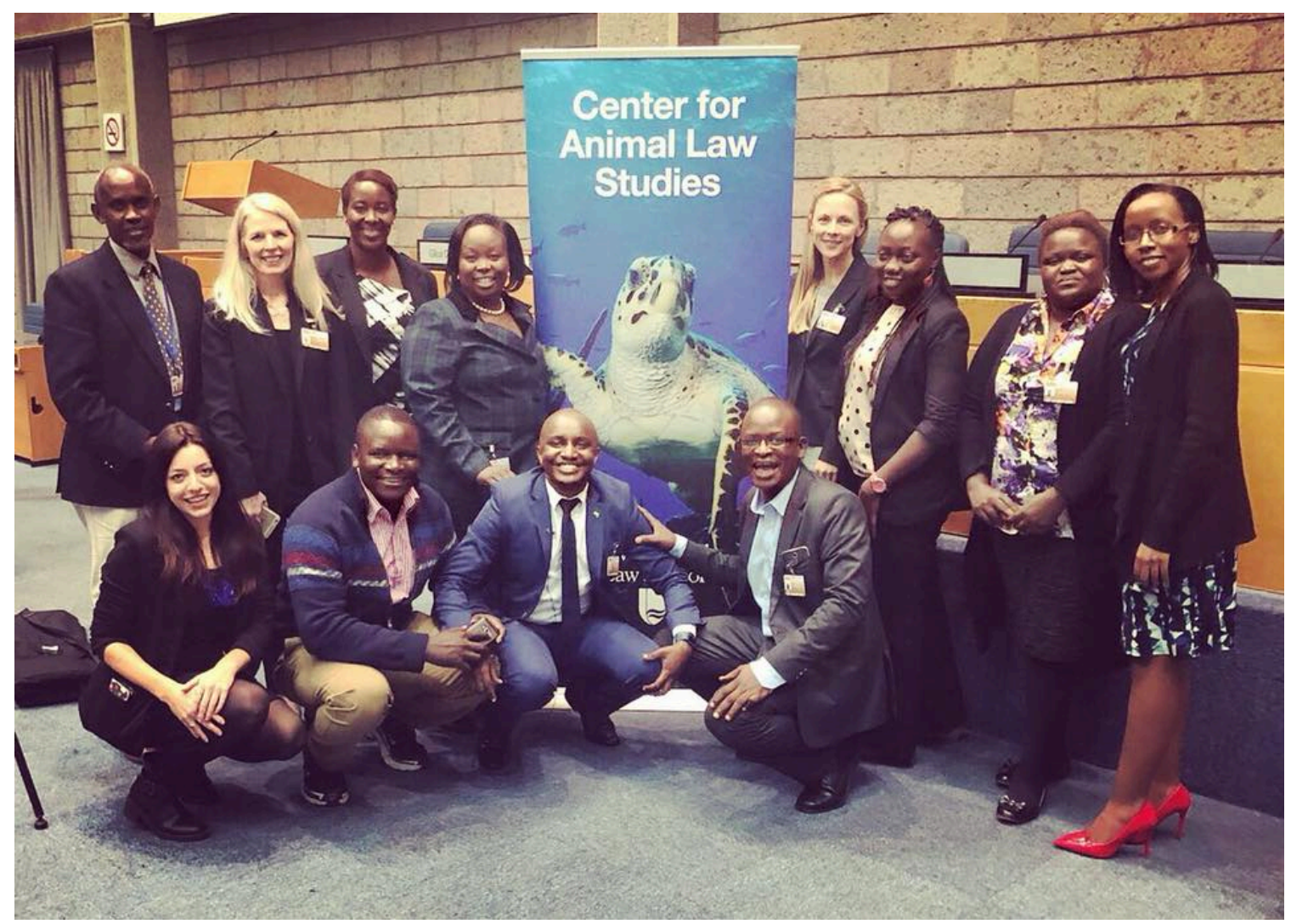

Some of the LL.M. Alumns with Associate Dean Pamela Frasch, International Director Natasha Dolezal and students that attended the Convention (Source: Accessed through Google Drive

Link: https://www.aawconference.org/index.php/en/about-the-conference/2018-conference-photos) 


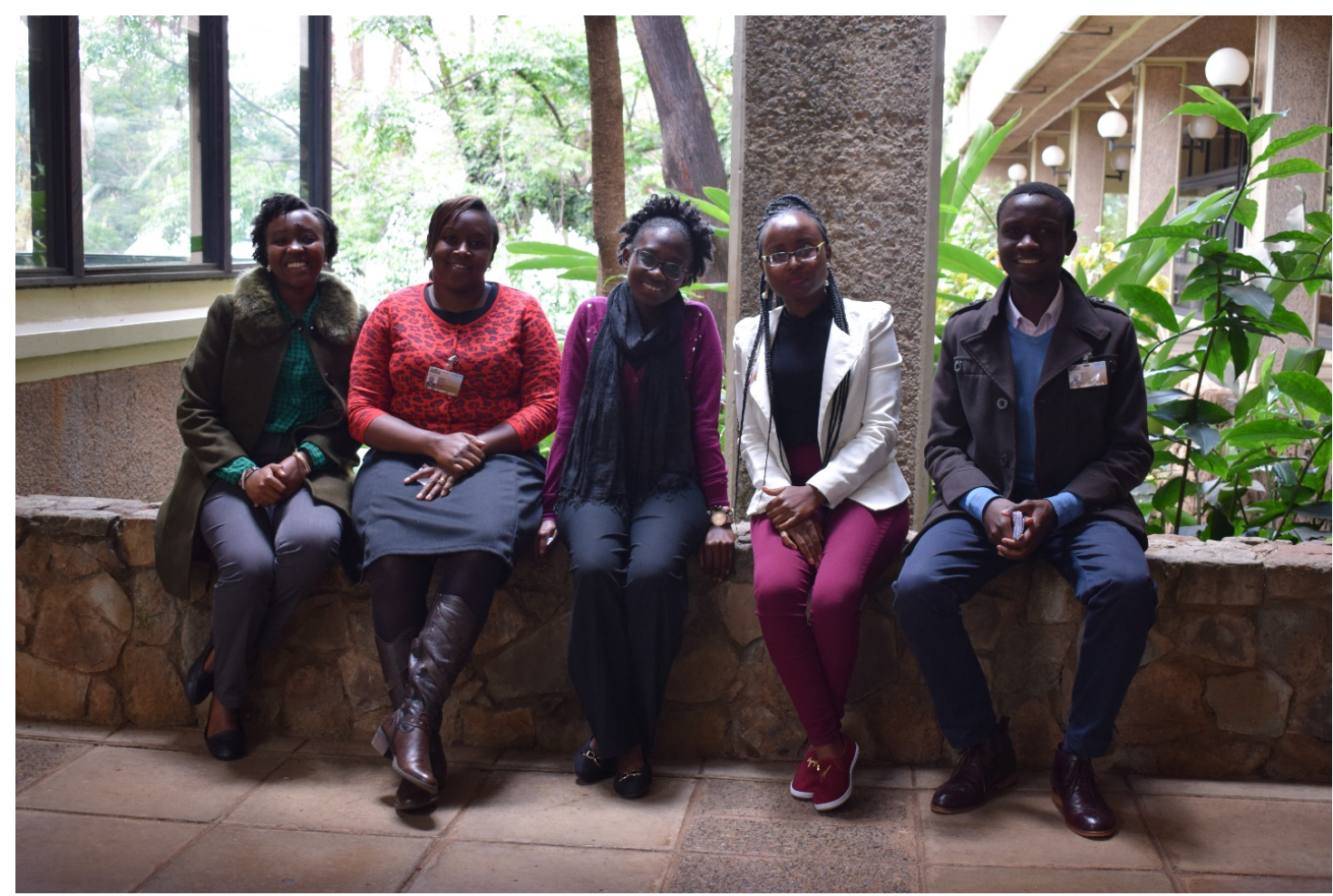

Some student attendees of the Convention taking a break between sessions (Source: Accessed through Google Drive Link: https://www.aawconference.org/index.php/en/about-the-conference/2018-conference-photos) 